Int. Archs Allergy appl. Immun. 1979;58:I-V

\title{
Contents, Vol. 58, 1979
}

\section{No. 1}

Original Papers

Chasin, M.; Scott, C.; Shaw, C, and Persico, F.:

A New Assay for the Measurement of Mediator

Release from Rat Peritoneal Mast Cells 1

Jörbeck, H.; Carlsson, H. E.; Svenson, S. B.; Lindberg, A. A.; Alfredsson, G.; Garegg, P. J.;

Svensson, S., and Wallin, N.-H.: Immuno-chemistry of Salmonella O-Antigens. Specificity and Cross-Reactivity of Factor 09 Serum and of Antibodies against Tyvelose $\cdot L^{1} / 8 \cdot$ Man-nose

Coupled to Bovine Serum Albumin .... 11

Ahlstedt, S.; Kristofferson, A., and Pettersson, E.: Antigens in Penicillin Allergy. III. Antigen and Antibody Levels in Mice Treated with Pure and Contaminated Penicillins 20 Bernstein, I. L.; Michael, J.G.; Malkiel, S.; Sweet, L.C., and Brackett, R.G.: Immunoregulatory Function of Specific IgG. II. Clini cal Evaluation of Combined Active and Passive Immunotherapy 30

Schuhmacher, M.J. and Jeffery, S.E.: Effect of Quantity and Quality of IgG Antibodies on Blocking of Allergenic Histamine Release in vitro 38

Ruddle, N.H.: Delayed Hypersensitivity to Soluble Antigens in Mice. II. Analysis in vitro ... 44 Oers, M.H.J. van; Pinkster, J., and Zeijlemaker, W.P.: Cooperative Effects in Mitogen- and Antigen-Induced Responses of Human Peripheral Blood Lymphocyte Subpopulations. . 53 Kasukawa, R.; Ohara, M.; Yoshida, H., and Yoshida, T.: Pregnancy-Associated «i-Glycoprotein in Rheumatoid Arthritis 67 Lindberg, J.; Kaijser, B.; Lindholm, A.; Hermodsson, S., and Iwarson, S.: Humoral Immunoreactivity in Chronic Active Hepatitis: Relation to HLA Antigens 75 Mauch, H. and Kümel, G.: A Solid-Phase Radioimmunoassay to Detect Anti-Tuberculin Anti bodies in the Guinea Pig 82 Helm, R.M.; Conrad, D.H., and Froese, A.: Lentil-Lectin Affinity Chromatography of Surface Glycoproteins and the Receptor for IgE from Rat Basophilic Leukemia Cells .... 90 
Ljungström, I. and Holmgren, J.: In vivo Suppres sion of Allograft Rejection by Cyclic AMP In creasing Agents 99

Rumpold, H.; Kraft, D.; Scheiner, O., and Ra-daszkiewicz, T.: Influence of Carbonyl Iron Treatment on Lymphocyte Subpopulations .. 105 Ben-Efraim, S.; Ophir, R.; Teitelbaum, R.; Zimber, C.; Barbash, G., and Weiss, D. W.: Effect of the MER Tubercle Bacillus Fraction on the Responsiveness of Mice to T-Independent An tigens 110

Book Reviews 119

Varia 120

No. 2

Original Papers

Meade, C.J.;Sheena, J., andMertin, J.: Effects of the Obese (ob/ob) Genotype on Spleen Cell Im mune Function 121

Binns, R.M.; Vaiman, M.; Davies, H.ff. S., and Symons, D. B. A.: Characterization of Lym phocyte Subpopulations by Adherence to $\mathrm{Ny}$ lon Wool 128 Camussi, G.; Tetta, C, and Cappio, F. C.: De tection of Immune Complexes on the Surface of Polymorphonuclear Neurophils 135 Allan, R.; Rodrick, M.; Knobel, H.R., and Isliker, H.: Inhibition of the Interaction between the Complement Component Clq and Immune Complexes 140

Pick, E.; Honig, S., and Griffel, B.: The Mecha nism of Action of Soluble Lymphocyte Media tors. VI. Effect of Migration Inhibitory Factor (M1F) on Macrophage Microtubules 149 Miyachi, S.; Lessof, M.FL; Kemeny, D.M., and Green, L. A.: Comparison of the Atopic Back ground between Allergic and Non-Allergic Beekeepers 160 Strannegård, I.-L. and Strannegård, Ö.: Stimula tory and Inhibitory Effects of Cyclic AMP on Lymphocytes from Atopic Children 167 Strannegård, I.-L.: Lymphocyte Stimulation with Phorbol Myristate Acetate in Atopic and NonAtopic Individuals 175 Contents IV 
König, W. and Henn, H.-W.: On the Latency Pe riod of Sensitization: Inhibition of Passive $\mathrm{Cu}$ taneous Anaphylaxis by a Factor in Normal Rat Serum 182

Ngan, J. and Kind, L. S.: Suppression of IgE An tibody Formation in Mice: Requirement for T-T Lymphocyte Interaction 195

Clark, C.; Jauregui, H.; Azar, M., and Wheelock, M.: Characterization and Quantitation of Murine-Delayed Hypersensitivity Responses Eli cited with Particle-Associated Human y-Globulin 202

Herzer,P.; Czarnetzki,B.M.; Holzmann,H., and

Lemmel, E. M.: Immunological Studies in $\mathrm{Pa}$ tients with Alopecia Areata 212

Smith, C. I. E. and Hammarström, L.: Regulation of Lymphocyte Activation by Serum Factors 219

Parnham, M.J.; Schoester, G.-A.P.; Kwast, T. H. van der, and Benner, R.: Alterations in

Granulation Tissue Growth Induced in vivo by Lymphocytes from Adjuvant-Diseased Rats . 227

Short Communications

Turner, K.J.; Feddema, L., and Quinn, E.H.:

Non-Specific Potentiation of IgE by Parasitic

Infections in Man 232

Turk, J.L. and Parker, D.: Sensitization of Gui nea Pigs to Levamisole 237

No. 3

Original Papers

Huggins, K.G.; Roitt, I.M.; Brostoff, J., and

Taylor, W. A.: Standardization of Radioallergosorbent Test (RAST) and Allergen Extracts in Terms of the WHO Standard for IgE 241 Thomson, A. W.; Hunter, C.B.J.; Cruickshank, N., and Home, C.H.W.: Study of PregnancyAssociated alpha2-Glycoprotein in Relation to Populations of Human Blood Leucocytes .... 251 Kasahara, T.; Kin, K.; Itoh, Y.; Kawai, T.; Morita, M., andShioiri-Nakano, K.: Cellular Co operation in Lymphocyte Activation. I. Co operative and Noncooperative Responses of Human T and B Lymphocytes to Various Mitogens 260

Sjöholm, A.G.: Complement Components and Complement Activation in Acute Poststreptococcal Glomerulonephritis 274

Smith, F. and Miller, J.F.A.P.: Delayed Type Hypersensitivity to Allogeneic Cells in Mice. I. Requirements for Optimal Sensitization and Definition of the Response 285 
Smith, F. and Miller, J.F. A.P.: Delayed Type

Hypersensitivity to Allogeneic Cells in Mice.

II. Cell Transfer Studies 295

Mizoguchi, Y. and Osier, A.G.: Effect of Cobra

Venom Factor on the Response of Wistar-

Furth Rats to the Gross-Virus-Induced

(C58NT)D Lymphoma 302

Andrews, B. S.; Mclntosh, J.; Petts, V., and Pen

ny, R.: Circulating Immune Complexes in

Acute Uveitis: A Possible Association with the

Histocompatibility Complex Locus Antigen

B27 313

Ring, J. and O'Connor, R.: In vitro Histamine and

Serotonin Release Studies in Atopic Derma

titis 322

Neveu, P.J.: Attempts to Modulate the Immune Response to a Hapten-Carrier Complex with Various Hapten-Containing Compounds .... 331

Apold, J.; Elsayed, S.; Aukrust, L., and Bennich,

H.: The Allergenic Structure of Allergen M

from Cod.III. Studies on the Antigenicity of

Long-Sequence Peptides 337

Bruynzeel, P. L. B. and Berrens, L.: IgE and IgG4

Antibodies in Specific Human Allergies 344

Pauwels, R.;Bazin, H.;Platteau, B., and Van Der

Straeten, M.: Relation between Total Serum

$\operatorname{IgE}$ Levels and IgE Antibody Production in

Rats 351

Short Communications

Maguire, H.C., jr.: Half-Body X-Ray Suppresses

the Acquisition of Delayed-Type Hypersensi

tivity in the Mouse 358

Hodinka, L.; Merétey, K., and Bozsóky, S.: Skin

Manifestations and Serum IgE Levels in

Levamisole-Treated Rheumatoid Arthritis

Patients $\quad 362$

No. 4

Original Papers

Leung-Tack, J.; Maillard, J., and Voisin, G.A.:

Chemotaxis Inhibition Induced in Polymor-

phonuclear Neutrophils by Soluble Immune

Complexes 365

Contents

$\mathrm{V}$ 
Aukrust, L.: Crossed Radioimmunoelectrophoretic Studies of Distinct Allergens in Two Ex tracts of Cladosporiwn herbarum 375

Mitchell, G. F. and Clarke, A. E.: Allergenicity of

Concanavalin A in Mice 391

Virella, G.; Hipp, W. A.; John, J.F.,jr.; Kahaleh, B.; Ford, M., and Fudenberg, H.H.: Nephelometric Detection of Soluble Immune Com plexes: Methodology and Clinical Applica tions 402

Hazra, P. K.; Sehgal, S.; Naik, S., and Aikat, B.

K.: Human T Cell Receptors for Monkey

Erythrocytes 411

Sewell,H.F.; Gell, P.G.H., and Basu, M.K.:

Immune Responsiveness and Oral Immuniza

tion 414

Mizushima, Y.; Mori, M.; Ogita, T., and Naka-mura, T.: Adjuvant for IgE Antibody and IsletActivating Protein in Bordetella pertussis 426

Forsberg, K. and Sörenby, L.: Release of Slow-

Reacting Substance from Anaphylactic Lung

Tissue and Its Modofication by /?-Sympathomimetics 430

Tesch, H; König, W., and Frickhofen, N.: Eo-sinophil Chemotactic Factor. Release from

Human Polymorphonuclear Neutrophils by

Arachidonic Acid 436

Gold, E. F.; Ophir, R., and Ben-Efraim, S.: Inhibition of Mixed-Lymphocyte Reaction by Quinine and Lack of Effect on Plaque-Forming Cells and Lymphoid-Derived Tumor Cells ... 447

Meriney, D. K.; Wallace, D.; Miller, J.; Goel, Z.

A., and Grieco, M.H.: Clinical Comparsion

of Skin Testing and the Radioallergosorbent

Test in Dog-Sensitive Patients Using Mixed

and Breed-Specific Antigens 453

Leonard, E.J.; Lett-Brown, M. A., and Askenase, P.W.: Simultaneous Generation of TuberculinType and Cutaneous Basophilic Hyper-sensitivity at Separate Sites in the Guinea Pig 460

Short Communications

lannelli, D. and Capparelli, R.: Immunogenetics oftheMcBl Macroglobulin Allotype in Cattle 470

Ito,K.; Ogita, T.; Suko, M.; Mori, M.; Kudo,

K.; Hayakawa, T.; Okudaira, H., and Horiu-

chi, Y.: IgE Levels in Nude Mice 474

Book Review 476

Author Index 477 